\title{
Analiza efektywności trakcyjnej zestawu kół pojazdu szynowego w luku toru o małym promieniu
}

\begin{abstract}
Przedmiotem opracowania jest studium efektywności trakcyjnej tramwajowego zestawu kót w tukach toru o matym promieniu krzywizny. Pojęcie ,,mały promień tuku” zostało ściśle technicznie zdefiniowane, jako zwiqzane zarówno ze zjawiskiem mikropoślizgów kót po szynach jak i z parametrami geometrii toru. W podsumowaniu sformułowano wniosek praktyczny.
\end{abstract}

\section{Wprowadzenie}

Rozważono przypadek indywidualnego napędu osi tramwajowego zestawu kół. Siły trakcyjne (podłużne) F kół zestawu, lewego „L” i prawego „P”, można traktować jako ogólnie niejednakowe. Przy takim założeniu wprowadzono pojęcie współczynnika efektywności trakcyjnej zestawu $\mathrm{E}_{\mathrm{TZ}}$, będącego wyróżnikiem konstrukcyjnej przydatności układu napędowego tramwaju do pracy w łuku torowym.

Współczynnik $\mathrm{E}_{\mathrm{TZ}}$ wyraża się wzorem:

$$
\mathrm{E}_{\mathrm{TZ}}=1-\frac{\left|\mathrm{F}_{\mathrm{L}}-\mathrm{F}_{\mathrm{P}}\right|}{\left|\mathrm{F}_{\mathrm{L}}\right|+\left|\mathrm{F}_{\mathrm{P}}\right|}
$$

Maksymalny potencjał trakcyjnych sił (przyczepności) na obwodzie kół zestawu opisuje zależność $F_{\text {zmax }}=\left|F_{\text {Lmax }}\right|+\left|F_{\text {Pmax }}\right|$. Jednak pod względem konstrukcyjnym z pełną efektywnością trakcyjną, wyrażoną według (1) wartością $\mathrm{E}_{\mathrm{TZ}}=1$, ma się do czynienia niezależnie od stopnia wykorzystania maksymalnego potencjału sił trakcyjnych.

Pod względem fizycznym konstrukcyjnego współczynnika efektywności trakcyjnej $\mathrm{E}_{\mathrm{TZ}}$ pojedynczego zestawu nie można bezpośrednio utożsamiać z eksploatacyjnym współczynnikiem $\Theta$ wykorzystania przyczepności [7] (albo wykorzystania nacisku napędnego) całego pojazdu dla celów trakcyjnych. Współczynnik $\Theta$ można wyrazić następującym wzorem:

$$
\Theta=\frac{\sum_{j=1}^{n} F_{j}}{\psi \cdot Q_{n}}
$$

gdzie:

- $F_{j}$ wypadkowa siła pociagowa wywiązywana na obwodzie j-tego zestawu napędnego

- $\psi=\psi(V)$ współczynnik przyczepności kół do toru przy prędkości $\mathrm{V}$ pojazdu trakcyjnego o liczbie ' $n$ ' osi napędnych i łącznym nacisku $\mathrm{Q}_{\mathrm{n}}$ tych 'osi' na tor.

Współczynnik $\mathrm{E}_{\mathrm{TZ}}$ dotyczy toru zakrzywionego, zaś $\Theta$ - toru prostego.
Zgodnie z (1), efektywność trakcyjna jest obniżona zawsze, gdy $\mathrm{F}_{\mathrm{L}} \neq \mathrm{F}_{\mathrm{P}}$. $\mathrm{O}$ ileż bardziej efektywność trakcyjną obniżałoby wystapienie ujemnej siły trakcyjnej (siły hamującej) na którymkolwiek kole zestawu. Taki przypadek może wystapić w huku toru przy dynamicznym niedostatku ,ekwiwalentnej stożkowatości” na zestawie. Ujemne wartości sił przyczepności (na kole zewnętrznym) w praktyce występują najczęściej w zestawach tocznych (nienapędzanych), w łukach toru o szczególnie małych promieniach, kiedy potencjal skrętnego napinania osi (w funkcji drogi pokonywanej przez zestaw) przyrasta tak szybko, że odprężanie tych napięć (na tej samej drodze) w wyniku mikropoślizgów kól nie nadąża za procesem napinania osi. W zestawach napędzanych lub hamowanych, siły przyczepności w łukach toru o znakach przeciwnych występują znacznie rzadziej i tylko przy względnie małym momencie napędowym lub hamującym na zestawie. Odpowiednią sytuację zilustrowano rys.1.

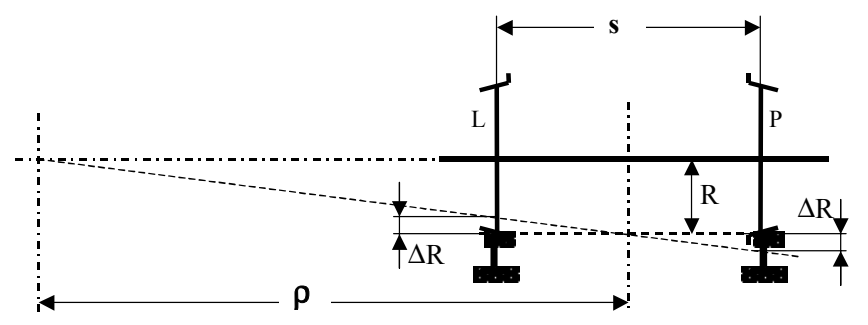

Rys. 1. Ilustracja geometrycznego bilansu stożkowatości kół zestawu pojazdu szynowego i tworzącej stożka w łuku toru o promieniu $\rho$

Jeżeli kinematyczne przemieszczenie poprzeczne środka zestawu w stosunku do środkowej linii (w tuku zazwyczaj nieco poszerzonego) toru zakrzywionego o promieniu łuku $\rho$ pozwala na osiagnięcie geometrycznych różnic promieni uprofilowanych kół lewego i prawego o łącznej wartości $2 \Delta \mathrm{R}$, to geometryczny bilans stożkowatości zestawu według rysunku 1 pozostaje zachowany, koła pracują bezpoślizgowo, zaś oś zestawu skrętnie się nie napina: 


$$
\frac{2 \Delta \mathrm{R}}{\mathrm{s}} \geq \frac{\mathrm{R}}{\rho} ; \quad \mathrm{R}=\frac{1}{2}\left(\mathrm{R}_{\mathrm{L}}+\mathrm{R}_{\mathrm{P}}\right)
$$

Związek (3) określa bezwzględne warunki technicznie pełnej efektywności trakcyjnej $\mathrm{E}_{\mathrm{TZ}}$ zestawu napędowego przy jednakowych naciskach obydwóch kół na szyny. Gdy zaś występuje niedostatek geometrycznej stożkowatości zestawu:

$$
\frac{2 \Delta \mathrm{R}}{\mathrm{S}}<\frac{\mathrm{R}}{\rho} ; \quad \mathrm{R}=\frac{1}{2}\left(\mathrm{R}_{\mathrm{L}}+\mathrm{R}_{\mathrm{P}}\right)
$$

to oś zestawu, przemieszczającego się wzdłuż toru, będzie doznawać narastających napięć skrętnych, przy czym wartość współczynnika efektywności trakcyjnej zestawu $\mathbf{E}_{\mathrm{TZ}}$ ulegnie odpowiedniemu obniżeniu. Biorąc pod uwagę występowanie poślizgów pomiędzy kołami i szynami należy oczekiwać, iż w praktyce wielkość $\Delta \mathrm{R}$ (według rysunku 1) będzie przybierać wartości inne niż wynikające z geometrycznego warunku ruchu bezpoślizgowego.

Zgodnie z (1), wartość trakcyjnej siły przyczepności pojedynczego zestawu $\mathrm{F}_{Z} \mathrm{w}$ każdych warunkach wyniesie:

$\mathrm{F}_{\mathrm{Z}}=\mathrm{E}_{\mathrm{TZ}} \cdot\left[\left|\mathrm{F}_{\mathrm{L}}\right|+\left|\mathrm{F}_{\mathrm{P}}\right|\right] ; \quad \mathrm{F}_{\mathrm{i}}=\mathrm{Q}_{\mathrm{Z}} \cdot \Psi_{\mathrm{i}}\left(\mathrm{V}_{\mathrm{i}}\right) ; \quad(\mathrm{i}=\mathrm{L}, \mathrm{P})$ gdzie:

$$
\begin{aligned}
& -Q_{Z} \text { nacisk statyczny zestawu kół na tor } \\
& -\Psi(V) \text { opisano przy wzorze (2) } \\
& -E_{T Z} \text { opisano wzorem (1). }
\end{aligned}
$$

Jest oczywiste, że w praktyce podczas ruchu zestawu w torze, naciski $Q_{i}$ kół na szyny nie są ani statyczne, ani jednakowe, lecz w sposób ogólnie losowy ulegają dynamicznym zaburzeniom nominalnej wartości grawitacyjnej. Zagadnienia dynamicznych zaburzeń nacisków nie mają zasadniczego związku z głównym wątkiem tematycznym opracowania i zostały pominięte.

Zagadnienie efektywności trakcyjnej $\mathrm{E}_{\mathrm{TZ}}$ zestawu w huku toru będzie analizowane przy upraszczającym założeniu jednakowych wartości nacisków kół zestawu na szyny. Ponadto, przy analizie mikropoślizgów podłużnych, dla uproszczenia przyjęto walcowy model koła. Uwzględniono przy tym fizyczne zjawisko poślizgu kół na szynach, co z kolei pozwoli na wyznaczenie rzeczywistych wartości $\Delta R$. Przy prezentacji zasad technicznej metody podnoszenia efektywności trakcyjnej zestawu tramwajowego w łuku wymienione uproszczenia nie mają istotnego znaczenia jakościowego.

2. Modelowy proces skrętnego napinania osi podczas bezpoślizgowego ruchu zestawu tocznego w luku toru

Odpowiednią sytuację zilustrowano rysunkiem 2.

Zestaw z kołami walcowymi ma okręgi toczne rozstawione na szerokości s. Podczas bezpoślizgowego toczenia się kół po szynach, w łuku toru o promieniu $\rho$, kąt $\varphi$ skręcenia osi przyrasta $w$ miarę przemiesz- czania się zestawu wzdłuż jego drogi. Równanie więzów kinematycznych (według rysunku 2):

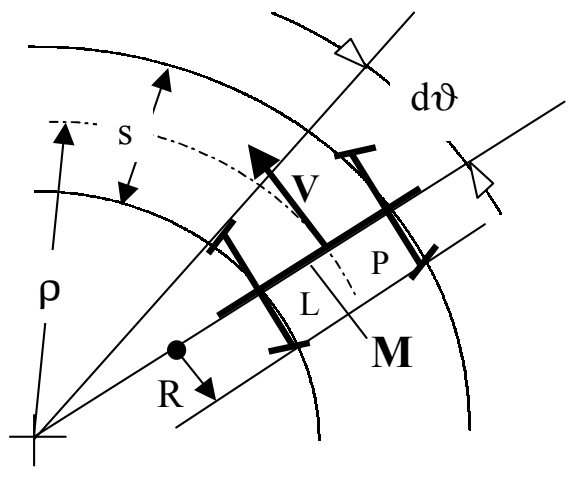

Koło prawe $\mathrm{P}$ pracuje w stanie „hamowania”; Koło lewe L pracuje w stanie „napędzania”. M- moment skręcający w osi

Rys. 2. Kinematyczny proces skrętnego napinania osi zestawu tocznego

Zestaw z kołami walcowymi ma okręgi toczne rozstawione na szerokości s. Podczas bezpoślizgowego toczenia się kół po szynach, w łuku toru o promieniu $\rho$, kąt $\varphi$ skręcenia osi przyrasta $\mathrm{w}$ miarę przemieszczania się zestawu wzdłuż jego drogi. Równanie więzów kinematycznych (według rysunku 2):

$$
\rho \cdot \mathrm{d} \vartheta=\mathrm{R} \cdot \mathrm{d} \Phi \Phi \mathrm{d} \Phi=\omega \cdot \mathrm{dt} ; \mathrm{V}=\omega \cdot \mathrm{R}
$$
gdzie:

- $\vartheta$ bieżący kąt położenia zestawu w planie łuku toru

- $\Phi$ kątowe położenie zestawu przy obrocie wokół jego osi

- V prędkość zestawu wzdłuż linii toru.

Przyrost d $\varphi$ kąta skręcenia osi wyraża się następująco:

$$
\mathrm{d} \varphi=\frac{\left[\left(\rho+\frac{1}{2} \mathrm{~s}\right)-\left(\rho-\frac{1}{2} \mathrm{~s}\right)\right] \mathrm{d} \vartheta}{\mathrm{R}}
$$

gdzie:

$-\mathrm{d} \varphi$ przyrost kąta $\mathrm{w}$ obrotu koła lewego względem prawego $\mathrm{w}$ zestawie.

Po podstawieniu (6) do (7) otrzymuje się:

$$
\mathrm{d} \varphi=\frac{\mathrm{s} \cdot \mathrm{d} \Phi}{\rho}
$$

Zatem kątowa prędkość skrętnego napinania osi wyniesie:

$$
\frac{\mathrm{d} \varphi_{\text {nap }}}{\mathrm{dt}}=\frac{\mathrm{s}}{\rho} \frac{\mathrm{d} \Phi}{\mathrm{dt}}=\frac{\mathrm{s} \cdot \mathrm{V}}{\rho \cdot \mathrm{R}}
$$

\section{Modelowy proces skrętnego odprężania osi pod- czas poślizgowego ruchu zestawu tocznego $\mathbf{w}$} luku toru [ 1 i 2 2]

Na skutek skręcenia liniowo sprężystej osi zestawu o kąt $d \varphi$, wystapi w niej moment skręcający $M$ (rysunek 2). W następstwie mikropoślizgów pomiędzy kołami i szynami, skręcenie osi będzie ulegać odprężaniu. Zgodnie z rysunkami 1 i 2, stwierdza się kolejno: 
- $\quad$ przy całkowitym skręceniu osi pomiędzy kołami o kąt $\mathrm{d} \varphi$, na obwodzie każdego koła zestawu o promieniu $\mathrm{R}$ można bilansowo przyporządkować przeciwnie skierowane przemieszczenia obwodowe o wartości $\frac{1}{2} \mathrm{R} \cdot \mathrm{d} \varphi$.

- aby droga $\frac{1}{2} \mathrm{R} \cdot \mathrm{d} \varphi$ została pokonana przez (abstrakcyjne) koło o promieniu $\Delta \mathrm{R}$, to zgodnie $\mathrm{z}$ rysunkiem 3 koło rzeczywiste musi obrócić się o kąt dФ.

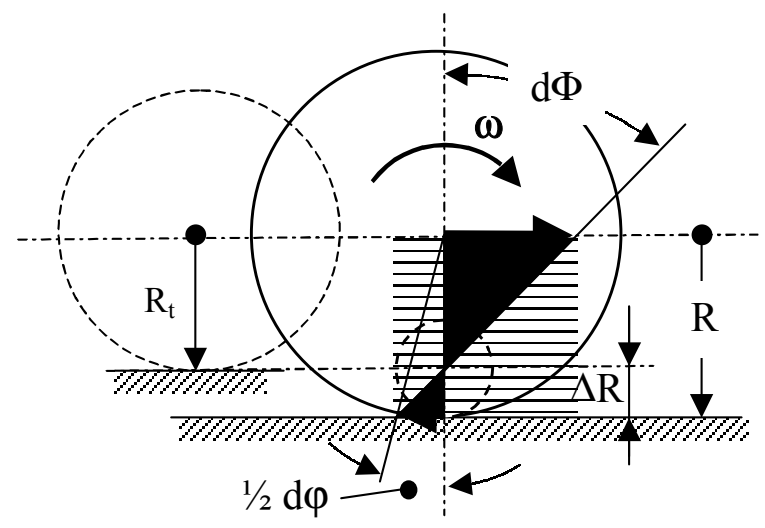

Rys. 3. Poślizg na kole wewnętrznym tocznego zestawu kół w luku toru.

$$
\frac{\mathrm{d} \Phi}{\mathrm{dt}}=\omega \approx \frac{\mathrm{V}}{\mathrm{R}}
$$

Kątowa prędkość elementarna poślizgowego odprężania osi wyniesie:

$$
\frac{\mathrm{d} \varphi_{\mathrm{odpr}}}{\mathrm{dt}} \approx \frac{2 \mathrm{~V} \Delta \Delta}{\mathrm{R}^{2}}
$$

Poziom skrętnych obciążeń w osi pozostanie ustalony, gdy prędkość poślizgowego odprężania osi zrówna się z prędkością kinematycznego napinania osi, czyli:

$$
\frac{\mathrm{d} \varphi_{\text {odpr }}}{\mathrm{dt}}=\frac{\mathrm{d} \varphi_{\text {nap }}}{\mathrm{dt}} \quad \text { albo } \quad \frac{\mathrm{s} \cdot \mathrm{V}}{\rho \cdot \mathrm{R}}=\frac{2 \mathrm{~V} \cdot \Delta \mathrm{R}}{\mathrm{R}^{2}}
$$

W wyrażeniu (14) występuje wielkość $\Delta \mathrm{R}$, którą należy wyznaczyć zgodnie $\mathrm{z}$ fizyką zjawiska poślizgu.

\section{Fizyczny charakter poślizgu [ 1 i 12 2]}

Trakcyjnie użyteczną siłę pociagową na pojedynczym kole zestawu o promieniu $\mathrm{R}_{\mathrm{L}}=\mathrm{R}_{\mathrm{P}}=\mathrm{R}$, przy nacisku statycznym koła na szynę $Q_{i}$, określa wartość poślizgu $\sigma$ [1,2 i 4].

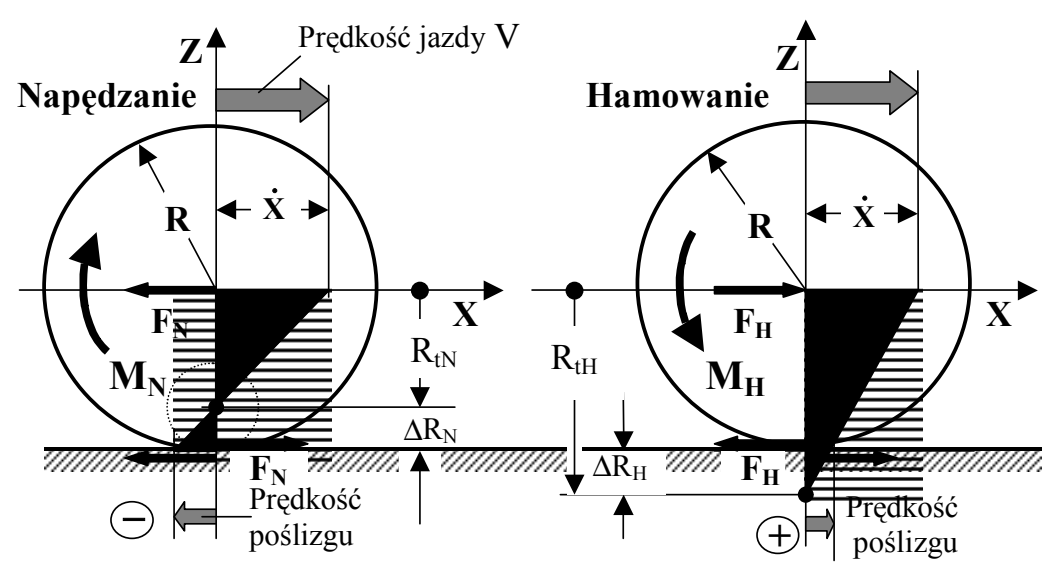

Rys. 4. Rozkład sił i prędkości poślizgów na kole napędzanym i hamowanym zestawu tocznego w łuku toru o małym promieniu

Elementarne drogi ślizgania na obwodzie koła (napędzanego - wewnętrznego lub hamującego - zewnętrznego podczas poślizgowego odprężania napięć skrętnych w osi zestawu kół), zgodnie z rysunkiem 3, bilansują się następująco:

$$
\mathrm{d} \Phi \cdot \Delta \mathrm{R}=\frac{1}{2} \mathrm{R}_{\mathrm{t}} \cdot \mathrm{d} \varphi \approx \frac{1}{2} \mathrm{R} \cdot \mathrm{d} \varphi
$$

gdzie: $R_{t}$ - promień toczny według rysunków 3 i 4 .

Zatem:

$$
\frac{\mathrm{d} \Phi}{\mathrm{dt}} \approx \frac{\mathrm{R}}{2 \Delta \mathrm{R}} \frac{\mathrm{d} \varphi}{\mathrm{dt}}
$$

Ponieważ w praktyce $\Delta \mathrm{R} / \mathrm{R}<<0,01$, to można napisać:
Według badań Cartera [3] przybliżenie liniowe tej zależności w technicznym obszarze użyteczności trakcyjnej jest opisane prostym wzorem analitycznym:

$$
\mathrm{F}=\mathrm{c} \cdot \sigma ; \mathrm{c}=70835 \sqrt{\mathrm{Q} \cdot \mathrm{R}}
$$

gdzie: c - wielkość stała (,stała Cartera").

Dla warunków toczenia się koła po szynie, napędzanego momentem $\mathrm{M}_{\mathrm{k}}$, poślizg wzdłużny $\sigma$ definiuje się poprzez prędkości: obwodową $\omega \cdot \mathrm{R}$ (mierzoną na obwodzie koła) i ruchu postępowego V (środka koła), co pokazano na rys.5.

Zatem:

$$
\sigma=\frac{\omega \mathrm{R}-\mathrm{V}}{\omega \mathrm{R}} ; \quad \omega \neq 0
$$



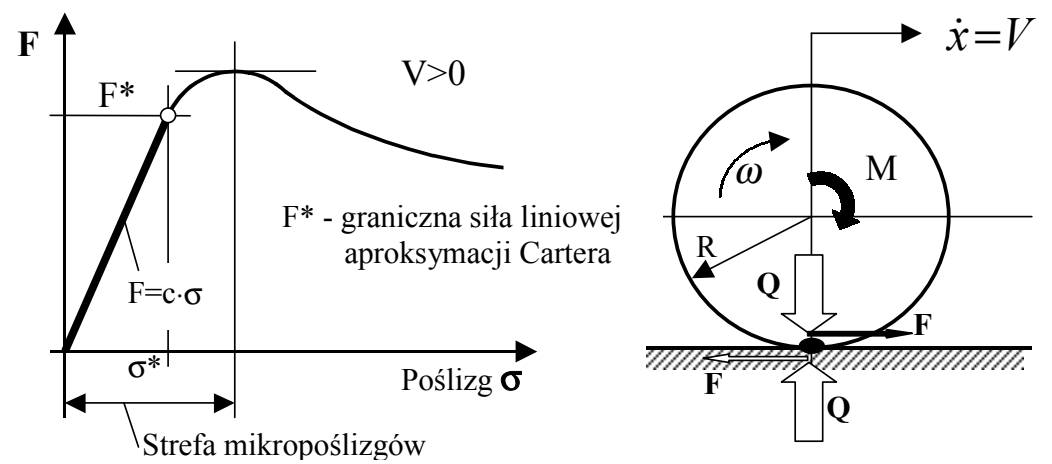

Rys. 5. Charakterystyka fizyczna [1, 3 i 7] sił przyczepności F koła do szyny wyrażona $\mathrm{w}$ funkcji poślizgu $\sigma$;

$$
\Delta \mathrm{R}=\frac{\mathrm{R} \cdot \mathrm{s}}{2 \rho} ; \quad \Delta \mathrm{R}=\mathrm{R}-\mathrm{R}_{\mathrm{t}}
$$

A także: różnica $\Delta \sigma$ kinematycznych poślizgów obydwóch kół zestawu w łuku jest niezależna od prędkości jazdy $\mathbf{V}$ i wynosi:

$$
\Delta \sigma=\frac{s}{\rho}
$$

\section{Związek wartości $\Delta \mathrm{R} \mathrm{z}$ efektyw- nością trakcyjną zestawu kól}

Jak wcześniej wspomniano, najsilniejszy spadek

Zgodnie z wzorem (16) koło walcowe, o nominalnym promieniu geometrycznym $\mathrm{R}$, obciążone trakcyjnie siłą styczną $F$, toczące się po szynie $\mathrm{z}$ poślizgiem $\sigma \neq 0$, ma na swym obwodzie prędkość obwodową $\omega$. $\mathrm{R}$, zawsze różną od prędkości ruchu środka tego koła $V=\dot{x}$ wzdłuż toru, gdyż (zgodnie z rysunkiem 4) każdej skończonej wartości sily $F$ zawsze towarzyszy poślizg $\sigma[6]$.

Według rysunku 3, obok omawianego koła trakcyjnego, z taką samą prędkością kątową $\omega$ może się bezpoślizgowo toczyć po swojej szynie inne koło, nieobciążone trakcyjnie, czyli „koło toczne” o promieniu $\mathrm{R}_{\mathrm{t}}$. Koło toczne, trakcyjnie nieobciążone, według (16) miałoby poślizg zerowy, czyli $\sigma=0$, zatem:

$$
\omega \cdot \mathrm{R}_{\mathrm{t}}=\mathrm{V} ; \quad \mathrm{V}=\dot{\mathrm{x}}
$$

Jeżeli koło toczne ma tak dobrany promień toczny $\mathrm{R}_{\mathrm{t}}$, że ściśle spełnia warunek (17), to na podstawie (16), można napisać:

$$
\sigma=\frac{\omega \mathrm{R}-\omega \mathrm{R}_{\mathrm{t}}}{\omega \mathrm{R}}=\frac{\Delta \mathrm{R}}{\mathrm{R}} ; \quad \mathrm{R}_{\mathrm{t}}=\mathrm{R}-\Delta \mathrm{R}
$$

Widać, że pojęcie abstrakcyjnego przyrostu promienia koła $\Delta \mathrm{R}$, będącego różnicą rzeczywistego promienia geometrycznego $\mathrm{R}$ walcowego modelu koła napędowego i promienia $\mathrm{R}_{\mathrm{t}}$ koła tocznego, (także walcowego), określa trakcyjny poślizg koła po szynie $\sigma$ zgodnie z (16).

Na mocy (14) i (18), każde koło zestawu tocznego doznaje następującego poślizgu:

$$
\frac{s \cdot V}{\rho \cdot R}=\frac{2 V \cdot \Delta R}{R^{2}}=\frac{2 V \cdot \sigma}{R}
$$

Albo:

$$
\sigma=\frac{\mathrm{s}}{2 \rho}
$$

skąd wynika, że przy stałym promieniu łuku toru $\rho$, różnica $\Delta \mathrm{R}$ promieni, fizycznego $\mathrm{R} i$ abstrakcyjnego tocznego $R_{t}$, w zestawie „walcowym” jest niezależna od prędkości jazdy $V$ i wynosi: efektywności trakcyjnej zestawu występuje, gdy siły obwodowe na kołach zestawu maja znaki przeciwne (rys.5).

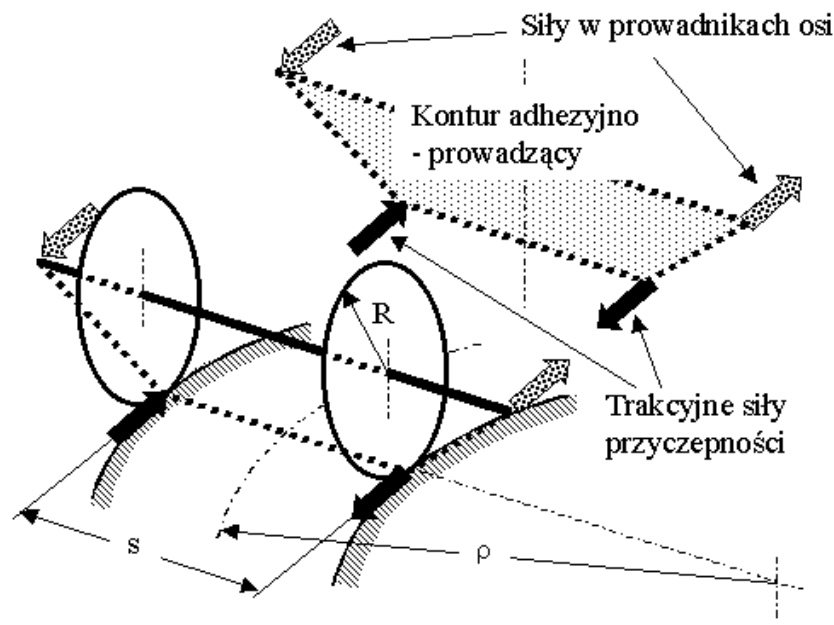

Rys. 6. Trakcyjnie nieefektywny kontur sił adhezyjnych oraz prowadzących w zestawie tocznym [5].

Warunek niewystępowania przeciwnie skierowanych obwodowych sił przyczepności na kołach zestawu wyraża się następująco:

$$
\frac{\mathrm{d} \varphi_{\text {odpr }}}{\mathrm{dt}}>\frac{\mathrm{d} \varphi_{\text {nap }}}{\mathrm{dt}}
$$

czyli w postaci jawnej:

$$
\frac{2 \Delta R}{s \cdot R}>\frac{1}{\rho}
$$

albo, po uwzględnieniu (18):

$$
\rho>\frac{s}{2 \sigma}
$$

Warunek (17) jest zawsze spełniony przez zestaw napędny (lub hamujący):

- na torze prostym $\rho=\infty$ przez dowolny klasyczny kolejowy zestaw kół

- przez pojazd jednoszynowy $s=0$ na dowolnym torze. 
Graniczną wartość promienia toru $\rho_{g r}$, przy której na żadnym kole zestawu tocznego podczas normalnej eksploatacji nie wystapi ujemna siła trakcyjna, można wyznaczyć wprost na podstawie (9), (15) oraz (19):

$$
\rho_{g r}=\frac{s}{2 \sigma^{*}}=\frac{s \cdot c}{2 F^{*}}
$$

gdzie:

- F* trakcyjna siła styczna na obwodzie kół zestawu, wg rys. 5.

- c stała Cartera we wzorze (15), według rysunku 5.

Według (26) „mały promień luku” występuje, gdy $\rho<\rho_{g r}$.

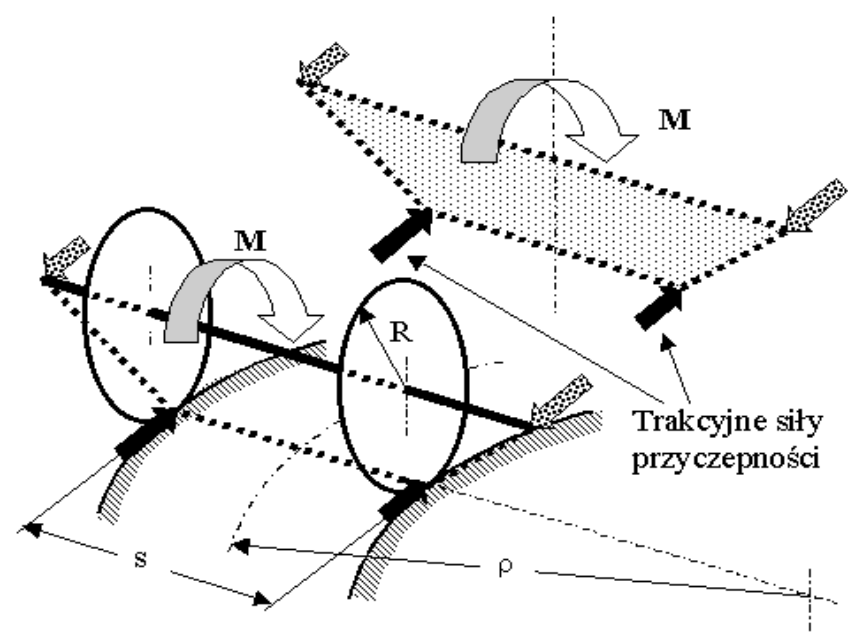

Rys. 7. Trakcyjnie efektywny kontur sił adhezyjnych i prowadzących w zestawie napędnym (lub hamującym elektrodynamicznie) [5].

Jeżeli obwodowe, przeciwnie skierowane siły przyczepności osiagają $\mathbf{w}$ luku wartości graniczne, to moment trakcyjny działający na osi ma na celu najpierw zniwelowanie na kole wewnętrznym siły trakcyjnie szkodliwej, a dopiero później wywołanie siły o zwrocie trakcyjnie użytecznym. Ponieważ poślizgi poszczególnych kół zestawu w łuku zawsze różnią się pomiędzy sobą, to także siły obwodowe na kołach będą się odpowiednio różnić. Obwodowa siła przyczepności na kole nie może przekroczyć siły maksymalnej według rys. 5 .

a)

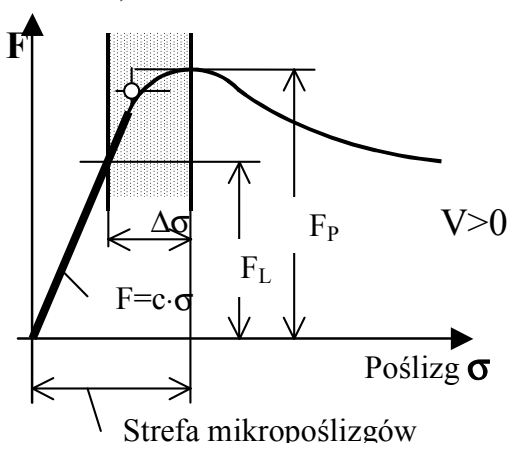

W łuku torowym wartości poślizgów względnych na kołach zestawu (tocznego, napędnego lub hamującego) będą zawsze różne, zatem różnica wartości poślizgów pomiędzy kołem lewym i prawym w huku wyniesie $\Delta \boldsymbol{\sigma}=\mathbf{2} \sigma(\rho)$. Gdy promien krzywizny toru $\rho=$ const, to zgodnie z (1), efektywność trakcyjna zestawu podczas eksploatacji w oczywisty sposób zależy od położenia pasma $\Delta \sigma$ (według wzoru 22) na wykresie $F(\sigma)$ - rys.8.

Indeksy „L” i „P” oznaczają odpowiednio koło lewe i prawe podczas ruchu zestawu w łuku „w prawo”.

$\mathrm{Na}$ rys. 8a pokazano przypadek eksploatacyjny $F_{P}>F_{L}$ przy czym $d F / d \sigma>0$, zaś na rys. $8 b F_{L}>F_{P}$, przy 'zym $\mathrm{dF} / \mathrm{d} \sigma<0$, co ilustruje przypadek awaryjny, $\mathrm{w}$ tórym poślizg $\sigma$ narasta $\mathrm{w}$ sposób niekontrolowany, rzy czym wartości sił $\mathrm{F}_{\mathrm{L}}$ i $\mathrm{F}_{\mathrm{P}}$ odpowiednio maleją.

Ilustracja przypadku eksploatacyjnego 8a) pokazu$\therefore$ że na mocy wzoru (1) zmniejszenie szerokości asma $\Delta \sigma$ byłoby bardzo korzystne. Zmniejszanie $\Delta \sigma$ bliża też pokazany na rys. 8 b) przypadek $\mathrm{E}_{\mathrm{TZ} \mathrm{OPT}}$ do rartości $\mathrm{E}_{\mathrm{TZmax}}=1$. Przypadek 8 b) pokazuje, że nawet o zerwaniu przyczepności $\mathrm{E}_{\mathrm{TZ}}<1$.

Pod względem formalnym związek $\Delta \mathrm{R} z$ efektywością trakcyjną wynika wprost $\mathrm{z}$ liniowej zależności 27), wynikającej z wzorów (21) i (22):

$$
\Delta \mathrm{R}=\frac{\mathrm{R}}{2} \Delta \sigma
$$

\section{Podsumowanie i wnioski}

Uproszczony model mikropoślizgu trakcyjnego, przy znanej wartości współczynników c i $\sigma$, pozwala na bardzo proste i dostatecznie wierne (dla celów modelowania dynamicznego) uwzględnienie wzdłużnych, trakcyjnych skutków złożonych zjawisk adhezyjnych. Pojęcie poślizgu opisanego poprzez abstrakcyjne przyrosty $\Delta \mathrm{R}$ promienia koła jest szczególnie czytelne dydaktycznie i łatwe w zastosowaniach obliczeniowych. b)

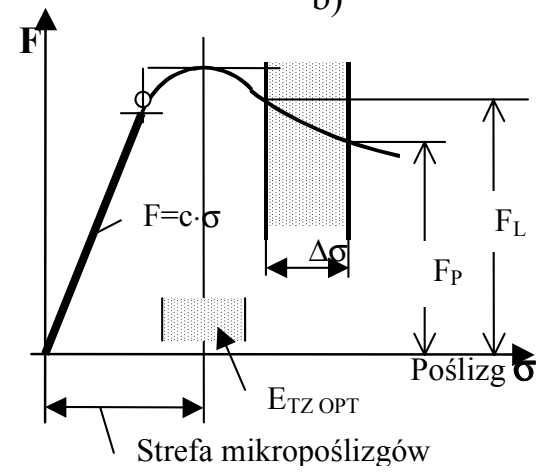

Rys. 8. Poślizgi trakcyjne: a) w normalnej eksploatacji napędnej i b) w stanie awaryjnym (po zerwaniu przyczepności). 
Model odwzorowuje tylko mikropoślizgi podłużne; poślizgi poprzeczne wymagają oddzielnego potraktowania. Model jest adekwatny do badania dynamiki pojedynczych kół oraz zestawów kolejowych kół napędzanych i nienapędzanych (tocznych). Model z dobrą dokładnością obejmuje przypadki techniczne $0 \leq \frac{\Delta \mathrm{R}}{\mathrm{R}} \leq 1$ Model formalnie nie obejmuje granicznego przypadku zablokowania koła przez hamulec kiedy $\Delta \mathrm{R}=\infty$; Wtedy ma się do czynienia $\mathrm{z}$ klasycznym przypadkiem tarcia (a nie przyczepności). Model formalnie dotyczy koła „walcowego”. Mikropoślizgi poprzeczne, spin (poślizg wiertny) i nabieganie obrzeża na szynę należy uwzględniać przy użyciu oddzielnego modelu fizycznego i odpowiedniego opisu matematycznego. Badanie podłużnej (płaskiej) dynamiki trakcyjnej całego pojazdu i dynamiki układów napędowych najkorzystniej powinno być prowadzone łącznie. Quasistatyczne obciążenia pasożytnicze konturu dynamicznego zestawu kołowego oraz dynamiczne zaburzenia nacisku tego zestawu na tor obniżają jego użytkową wydajność trakcyjną (współczynnik efektywności trakcyjnej jest mniejszy od jedności).

Niepełne wykorzystanie przyczepności przez choćby jedno koło zestawu kół obniża efektywność trakcyjną tego zestawu. Stąd także wynika oczywisty wniosek, że niepełne wykorzystanie przyczepności przez choćby jedno koło pojazdu trakcyjnego także w pewnym stopniu obniża trakcyjną efektywność całego pojazdu. $Z$ powodu sprzecznych wymagań odnośnie do budowy zestawu dla zapewnienia statecznego ruchu zestawu w torze prostym i wysokiej efektywności trakcyjnej w łuku, konieczny jest techniczny kompromis.

W łuku torowym o promieniu $\rho<\frac{R \cdot s}{2 \cdot \Delta R}$ według wzoru (4), efektywność trakcyjna $\mathrm{E}_{\mathrm{TZ}}$ zawsze jest mniejsza od 1, zatem w trakcji tramwajowej należy stosować układy napędowe z mechanizmem różnicowym o odpowiednio dobranej strefie nieczułości różnicowej dla kompromisowego zapewnienia właściwości klasycznego zestawu kół w torze prostym przy eliminacji ujemnych sił trakcyjnych w tukach według wzoru (26) oraz przy zachowaniu możliwie wysokiej wartości współczynnika $\mathrm{E}_{\mathrm{TZ}}$. Tematyka ta zostanie omówiona $\mathrm{w}$ oddzielnym artykule.

\section{LITERATURA}

[1] Grzesikiewicz W., Piotrowski J.: On the Development of the Traction Force between Wheel and Substrate. A Selection of Simple Mathematical Models. Machine Dynamics Problems. Vol. 17, 1997.

[2] Grzesikiewicz W., Piotrowski J., Zaborowski J.: Rozwijanie sity trakcyjnej przez koło pojazdu szynowego. Teoria uproszczona. Prace XII Konferencji „Pojazdy Szynowe” Poznań 1996.

[3] Grzesikiewicz W., Osiecki J., Piotrowski J.: Podstawy dynamiki pojazdów szynowych. Skrypt P.W. Warszawa, 1974.

[4] Madej J.: Mechanika napędu pojazdów szynowych... PWN Warszawa 1983.

[5] Madej J.: Mechanika transmisji momentu trakcyjnego. Oficyna Wyd. P.W. Warszawa 2000.

[6] Madej J.: Teoria ruchu pojazdów szynowych. Oficyna Wyd. P.W. Warszawa 2004.

[7] Menszutin N.N. Zawisimost meżdu siloj sceplenja i skorostiu skolżenja kolesnoj pary lokomotiva. Westnik WNIIŻT Nr 7/1960. 